ARTICLE

\title{
INTERDISCIPLINARY APPROACH TO THE STUDY OF STATE SOCIO-ECONOMIC SYSTEMS
}

(D) PRYIATELCHUK, Olena*

Doctor of Economic Sciences, professor of the Department of International Business, Institute of International Relations, Taras Shevchenko National University of Kyiv, Ukraine. *Correspondence to (pryyatelchuk@gmail.com)

\section{COPYRIGHT NOTICE:} the Creative Commons Attribution (CC BY) license (https://creativecommons.org/licenses/by/4.0/).

\section{CITE THIS PAPER:}

Pryiatelchuk, Olena (2022). "Interdisciplinary Approach to the Study of State Socio-Economic Systems" Journal of World Economy: Transformations \& Transitions (JOWETT) 1(03):12. DOI: https://doi.org/10.52459/jowett13120122

\begin{abstract}
The success of implementing a state economic policy operating under the conditions of a particular economic model depends on the diversity of aspects. The social one is the most important among them. The social aspect of the economic system and politics is oriented first and foremost to human resources, which is the base of the social-economic system. In this article the interdisciplinary approach has been identified as a priority in the field of study of the essence and development of new types of socio-economic systems, considering the whole complex of factors of their environment of formation. The existence of a close interconnection of economic and social aspects has been determined: the influence of non-economic, including social, determinants on the development and functioning of innovative models of the state structure; ensuring social development through existing economic shifts. It's concluded that an interdisciplinary approach in analyzing the concept of sustainable development and finding ways of its implementation is a necessity.
\end{abstract}

\section{KEYWORDS}

Socialization, Economy, Solidarity, Competition, Social Well-Being, Socio-Economic Systems. 


\section{INTRODUCTION}

The usage of an interdisciplinary approach to the research and formation of state economic systems has become an actual trend of state planning and administration. Traditionally, the determining factors for building a particular type of economic system were the political course and the available logistical preconditions for the country's development. However, aspects of ethics, morality, psychology, and culture have become a prerequisite for the formation of the state economic system. Thus, traditionally the political and economic aspects of the construction of the state system have expanded due to sociology, psychology, and cultural studies.

However, the socialization of the state economic system is not an innovative phenomenon. Social coloring of economic systems is a common characteristic of all - even the most pragmatic economic systems. Let's define the essence, varieties of economic systems, and the level of their socialization.

In essence, the economic system is quite multifactorial and is constantly functioning and changing, being influenced by factors such as the existing system of economic decision-making in the country; ownership structure; mechanisms for providing information and coordination; methods of setting goals, and motivating people to productive work, etc.

The system-forming elements of the economic system include, first, socio-economic relations (correlation between production factors and labor results). Elements such as ownership, organization of labor, use of labor, the main types of economic systems, in fact, are different for each social-economic system. Thus, the most accepted approach is the separation of traditional, market, administrative (command), transitional and mixed economic systems (Pelkmans, 2012).

\section{HYPOTHESIS}

The traditional economic system is characterized by closeness from the outside world, dominance in the structure of the economy of the agricultural industry, natural exchange, barter operations, slow technological development; individual and simple cooperation in the field of labor organization, clan; limited personality development and almost impossible migration from the bottom of the social pyramid. Traditions passed down from generation to generation determine both the structure of production and the supply of goods and services and the main range of potential consumers.

In a market economy, private ownership usually prevails, free-market pricing laws are based on supply and demand. The regulatory role of the state is limited by the law-making system, that is, the principle of "invisible hand of the market", described by A. Smith, is implemented, according to which the state performs 
the functions of monitoring and control and, if necessary, eliminates certain distortions arising in the process of economic and social relations. Such participation of the state is necessary under the condition of impossibility of full market self-regulation and cyclicality of economic development, which implies the permanent onset of crisis phenomena. In a modern market economy, the state is forced to play an active regulatory role and to ensure a high level of social protection for all members of society.

One of the main advantages of a market economic system is the efficient allocation of resources, directed primarily to the production of goods and services for which there is a high demand ("invisible hand of the market"); freedom of choice and activity of entrepreneurs; promoting the quality of goods and services; flexibility and high adaptability to changing environments; stimulating scientific and technological progress. However, this system has also some disadvantages (Reinert, 1999). These include unequal distribution of income; instability of development, which often results in inflation, unemployment, social tension; insufficient funding for research, education, and health; imperfect competition; active merger and acquisition processes leading to partial market monopolization; uneconomical use of natural resources, etc.

The administrative (command) economic system is characterized by the centralization of management based on policy-driven planning and demand forecasting; high concentration of production and monopoly; exclusively state ownership; the presence of a cumbersome administrative and bureaucratic apparatus. Economic decisions are made mainly by government officials. Manufacturers are deprived of both their freedom of choice and interest in improving production efficiency. The positive features of a command economy include the economy of resources due to planning, the possibility of concentrating them on certain areas of economic activity; rapid response to unforeseen threats, including economic threats; ensuring economic and social stability. However, all the advantages are offset by such disadvantages as the impossibility of rapid development and implementation of scientific and technological progress; lack of freedom of production and consumption; low level of satisfaction of consumer demand; the emergence of the "black market" due to chronic shortage of consumer goods.

The transitional economic system is an intermediate (unstable, alternative, pre-crisis) state of economy without a pronounced form of ownership, which involves the use of wage labor, the existence of various types and forms of labor and production organization.

\section{DISCUSSION}

Currently, the most common is the mixed form of the economic system. Its research is not possible due to the multifaceted nature of the elements and methods and principles of their interaction without the use of a multidisciplinary approach. Any modern economy has elements of both the market (in particular, the consumer 
sector) and the planned (mainly in strategic sectors) economy, as well as the remnants of the traditional system (the production of authentic folk attributes of clothing, traditional food, etc.). A mixed economy is based on mixed forms of ownership, the interaction of free competition, the principle of state non-interference in the economy with simultaneous socialization of economic life (Esping-Andersen, 1990).

Even in the absence of standard schemes and the need to develop identical models with national features in mind, this system has several advantages. In particular, the positive features of a mixed economy are the creation of conditions for economic growth and stability; social guarantees; protecting and promoting free competition; combating monopolies; ensuring political stability; stimulation of technological and organizational innovations; support for education, culture, and science (Pryiatelchuk, 2019).

In a mixed economic system, the disadvantages of a market economy are offset by state regulation the direct involvement of the state in the provision of social goods. In general, the main functions of the state in the mixed economic system include:

- redistribution of income through the tax system and centralized funds;

- $\quad$ support for public sector enterprises;

- financing of education, culture, science, public order;

- impact on the redistribution of resources between sectors of the economy to prevent unemployment and production downturns.

In general, a mixed economy is a combination of elements of a market economy and a planned economy with a compulsory consideration of the social component. However, in different conditions, different methods of socialization of state regulation and business are possible, as well as a system of coordination of these relationships in the triad state-business society (individual).

A mixed economy involves the participation in economic control of both the state and individuals (business and society). In this system, there is freedom of economic activity and state interference in social security. Although a mixed economic system has a relatively short lifespan, it has been embraced by several developing countries, such as India, and industrialized countries, including the United States, the United Kingdom, as a system that provides rapid economic development.

The mixed economy is characterized by such features as the coexistence of the private and public sectors; personal freedom; existence and protection of private property institute; economic planning carried out by the state in order to fully promote the economic development of the country; state control over market pricing; antitrust regulation; avoidance of economic inequality; profitable activity and social security. The mixed 
economic system combines the incentives for entrepreneurial activity to obtain the profits inherent in capitalism, with the inclusive system of social insurance characteristic of socialism.

There are several types of mixed economy:

The mixed-economy capitalist model assumes private ownership of an overwhelming number of factors of production ( $\mathrm{REO}, 2019)$. The state does not interfere excessively in the economy, the main responsibility of the government lies in ensuring rapid economic growth, conducting antitrust measures to maintain a free-market environment.

The state retains ownership of the means of production under a socialist mixed system. Market mechanisms, such as market conditions, are used to make major economic decisions. However, government intervention remains to ensure sustainable economic growth, such as generating demand through the creation of a public procurement system. The socialist mixed system is implemented through a liberal or centralized model. In the context of a liberal socialist mixed economy, rapid economic growth rates remain continuous due to the timely intervention of the state in self-regulating market processes. In a centralized socialist mixed economy, major decisions are made by the government in accordance with the needs of the economy.

The main feature of a mixed economy is its socialization. One of the most common varieties of mixed economy is currently a socially-oriented market economy, a public welfare economy, a social economy, and more.

A socio-oriented market economy (socio-market economy) is an economic system organized based on market self-regulation. Under this system, both the state and the private business (the manufacturer of goods and the entity providing services) carry out their activities considering the needs and preferences of the consumer (an individual of society). This should be expressed as in the production and marketing activities, in which the manufacturer offers the product in accordance with the structure of demand, the general needs of society and considering such general needs as the environmental friendliness of production, utility, and harmlessness of manufactured products, the formation of a proper culture of consumption, which would ensure the development of society at a high-quality level (NCGM, 2019). At the same time, the manufacturer must adhere to the rules of business ethics, be a law-abiding taxpayer (since it is from the size of revenues to the budget that the structure of social payments is formed, and therefore the overall level of welfare of the society as a whole is established), to implement the concept of corporate social responsibility in the process of its activity, which would guarantee the implementation of social projects within the organization (compliance with labor laws, creation of proper working conditions, implementation of valeological and health projects, staff development, additional insurance, etc.), and the regions of operation (sponsorship and social projects, projects for the development of regions involved in providing quality reproduction of labor resources of the state in general). The state, in turn, 
actively coordinating and playing a key role in the implementation of social projects within the general socioeconomic policy of the state, should develop a sense of mutual responsibility of all market participants and coordinate unfair trends in competition, trade, and income sharing.

The concept of a social market economy is based on previously developed theories and is an element of pre-existing concepts, trends, and schools.

The basis for the emergence of the modern concept of the socio-market economy can be considered theories of liberalism, neoliberalism, ordoliberalism, and the concept of the German social market economy. However, in the opposite view of A. Müller-Armack, although the social market economy is closely related to the theory of neoliberalism, "its roots are in dynamic theory in philosophical anthropology that arose from other views on the state and the development of the concept of lifestyle, which has been largely denied by neoliberalism» (Janiszewska, 2015).

Based on the principles of A. Smith and D. Ricardo's teachings on the freedom of choice of producer and consumer as the key to the successful functioning of the market system, the theory of liberalism plays a leading role in the individual activity, driven by personal interest (Kolev, et al., 2014). Ensuring the greatest freedom of economic activity of the subjects must be combined with a clear limitation of the degree of state intervention in the economy. The theoretical postulates proclaimed supporters of liberalism can be represented by the following provisions:

- the market system is considered to be the most efficient economic system since it is able to create the best conditions for economic development and growth, under which the state provides only conditions for competition;

- the market system is capable of self-regulation, thereby ensuring the presence of natural order, which, in turn, shapes and maintains an optimal balance of personal and public interests;

- the freedom of activity impedes the formation of monopolies and the deepening of state interference.

Some theses inherent in the adherents of liberalism were reflected not only in the classics but also in Christian, especially Catholic doctrine. In particular, in the writings of A. Augustinus and T. Aquinas, the market is perceived as a mechanism of coordination, however, which perfectly functions only in the presence of appropriate institutional and social policies. Thus, the concept of the social market economy was primarily formed based on classical and Christian economic trends.

The next stage (beginning of the twentieth century) of the formation and development of the concept of the social market economy were the approaches of representatives of social institutionalism, in particular, $\mathrm{T}$. 
Veblen and W. Mitchell, who proved the imperfection of the market monopolized economy at that time. There was a need for a broader approach to solving economic problems, given the strong influence on the economy of social institutions and processes, in particular the state, law, trade unions, ethics, morality, religion, etc. According to the authors, these institutions were to provide the much-needed social control over the imperfect monopoly market. It was the economists-institutionalists who pointed out that legal, social, and moral factors influence the economy with material factors, which has a significant impact on the economic growth rate and the overall welfare of the country. Such a broad approach to economics has been a significant achievement of methodology and theory of economics.

Neoliberal economic and social projects, in turn, deny totalitarian social systems, allow for the presence of elements of state regulation in the economy, and emphasize the need to protect competition from monopoly power (primarily by establishing a system of public control overpower). Although the representatives of separate directions choose the different ways of overcoming the existing problems, (Chicago School - F. Knight, M. Friedman, London - L. Mises, Freibuz - W. Euken, L. Erhard), they are focused, first of all on a combination of individual and social freedom with the need to support socially vulnerable groups.

Advocating liberalism, while promoting the value of personal freedom, society viewed the social market economy as a program aimed at shaping the political, economic order and those areas in which freedom is a basic condition for efficiency.

The Ordoliberals proceeded from the assumption that only an economic order based on the freedom and responsibility of each individual can effectively provide society with limited goods and steadily increase the level of general well-being. The protection of competition is one of the main tasks of the state since it is the policy of perfect competition that is a condition for fairness for all. The principle of universal competition will resist the attempts of individuals and the state to monopolize the market. The developed system of a competitive market will allow all members of society, regardless of their social status, to maintain an adequate standard of living. That is, the level of well-being should be achieved by all members of society equally (the minimum level in all qualitative and quantitative indicators).

W. Euken argued that each particular system was based on a combination of human needs, natural conditions of labor, inventory, technical knowledge, legal and social order. The state should take an active direct part in the formation of the proper level of this order and its support until the established order acquires the natural, established, unchanged features. According to the scientist, the basic principles of such a free market economy system should be the inviolability of private property; stability of cash flows and national currency; open markets; freedom of agreements and contracts; responsibility of each individual for their economic decisions; sustainability of economic policy (Kolev, et al., 2014). 
A major contribution of the Ordoliberal School was the study of the relationship between the economic, political, state, and legal order. Thus, the horde of liberalism has attempted to create a coherent picture of an economic system that functions in the unbroken unity of economic and non-economic institutions.

Such works have largely contributed to the formation of the very concept of social market economy, the separation of theoretical approaches to its study as an independent scientific direction, one of the first representative of which was A. Müller-Armack, who justified the term "social market economy", which "was a socio-market order, which purposefully organized a free market economy in the presence of a regulatory system we give the competition a stronger guarantee of social progress precisely because social progress through a free system through the conscious development of free-market measures and the redistribution of revenues through the state budget, when competition development forms the economic base for social events, can be organized more effectively» (Janiszewska, 2015).

The idea of a social market economy, which suggested a combination of market economy and social justice, found its practical implementation in the German doctrine of the social market economy.

In particular, the argument for a new path of the social market economy for post-war Germany was: a sharp criticism of the centralized management of totalitarian economic systems combined with a simultaneous critique of the free market; isolation of free-market mechanism as a special management tool; the need to take into account the social component in the economy and the need for "socially motivated intervention" in it; isolation of separate (price, structural, housing, social, monetary) spheres where the market alone is not capable of delivering the results needed by society.

At that time, the German economic policy strategy for the creation of a new economy envisaged, first of all, the revival of market pricing, increased profits, and investment activity of enterprises; at the same time state control over the prices for essential food products, as well as oil, gasoline, transport, mineral fertilizers (Merkel, 2019).

In contrast to the ordoliberal concept of a socially-oriented market economy, the Scandinavian model of the social economy has been formed and is now developing. If the ordoliberal market model relies on the idea of free competition, the voluntary nature of wage-setting, and other key socio-economic parameters, the Scandinavian social-democratic model, in turn, gives the state governed by the public control system the main functions in the socio-economic sphere (NCGM, 2019).

However, under the current conditions, both models are practically identical due to the implementation of social partnership concepts and solidarity in practical terms. The socialization of the functioning of a market economic system is realized through a coherent system of tripartism - the state, society, and business. An 
important task of the state remains to ensure a balance between market efficiency and social justice, protection of legal rules governing economic activity, and at the same time ensuring the existence of a perfectly competitive environment. However, the level of activity of the state and its involvement in the social sphere in individual countries may differ, forming the characteristics of individual market economic systems.

Existing economic systems with elements of state regulation are steadily reducing the economic freedom of a particular individual and disrupting the market mechanism of pricing. Only in the conditions of the system of social market economy, it is possible to guarantee economic freedom concerning the state, entrepreneurs, and workers. Only a social market economy based on social justice can guarantee the realization of the best opportunities for comprehensive economic growth.

It is important to note that in this case social justice does not mean an equal distribution of income, but a fair (according to the results of the activity and contribution of an individual) distribution.

The key conditions for creating a social market economy include:

- creating of central administrative and legal bodies that carry out economic and financial policies under their own responsibility;

- carrying out tax reform by reducing the tax burden to a level that would stimulate personal economic interest in expanding production;

- reforming the financial system by drastically reducing costs and maintaining budgetary equilibrium in order to prevent debt;

- conducting antitrust policies to prevent possible abuse of power in the economy;

- replacement of imperfect regulated economy by a social market economic system.

The social market economy is the defining basis of economic and social policy, the essence of which, "instead of defining a policy that retains economic control, inhibiting free initiative in society can be defined as a social solution that combines all goals in the working, realistic harmony. That is, a socially-oriented market economy is an economic social system that provides high efficiency of a market economy and guarantees citizens on this basis the maximum of social justice, security, and socio-economic progress (Kuznetsova, 2015).

The basis of the social market economy is the freedom and responsibility of each individual (Laville, 2010). The market economy, promoted by the struggle for objective results of the competition, eliminates any possibility of the state abusing its economic power as an instrument of political power. In such circumstances, the task of public policy is to combine freedom, order, a harmony of individualism and collectivism to achieve the common welfare. The main purpose is to provide every member of society with the minimum necessary and 
to create the conditions under which anyone can provide himself or herself with the desired maximum under the desire and exertion of his or her own efforts.

After the establishment of a system of social market economy, the solution of social problems stays no longer in the prerogative of the state. The social security system becomes independent. In addition, citizens must independently control the administration of the bodies of this system.

The benefits of the social market economy model are sufficiently substantiated by the Hungarian economist A. Yasay. In his view, the socio-oriented market economy "borrows to some extent from capitalism the desire to make a profit in private property, but at the same time seeks to use the profit to achieve noble goals such as solidarity, social justice, and equality. This guarantees the efficient production of a social product in a free market" (Pryyatelchuk, 2018).

However, like any other system, a socially-oriented market economy, under certain conditions of practical functioning, can lead to several disadvantages. Protectionism of inefficient industries for the purpose of implementing social programs, active protection against foreign competitors of domestic producers, etc., ultimately leads to the destruction of the harmonious system of the national economy, increasing production costs, reducing the number of jobs, and eliminating incentives to create new ones, reducing the actual size of employee benefits and the like.

To avoid the formation of a high-cost economy that is incapable of developing, as the burden of implementing social projects is an undue burden, it is necessary to develop priority, most effective, highly profitable sectors of the economy, thereby avoiding the need for such social projects.

In this perspective, it is important to consider the initial principles: (1) social justice means not equal share for everyone but separate for each person, and (2) a successfully functioning socially-oriented economic system is not one where there are many social support projects for citizens. It is one in which there is no need for such programs since all the conditions are created for the possibility of everyone to raise the minimum level of well-being given to them (SPI, 2018).

The best social order does not exist where, through redistribution of the social product, the widest possible social support is provided, but where such support is required by the minimum number of citizens. The primary functions of the state include creating favorable conditions for the development and multiplication of human capital (HMR\&C, 2019). In the future, the degree of personal success will depend only on the level of development of the abilities and efforts spent to realize them. 
An integral part of any economic system is the social one, expressed in the development and implementation of socio-economic policies of the state. Thus, formally, any economic system is social. However, it is necessary to distinguish between categories of social market economy and social economy.

The social market economy is a developed economic system, widespread among industrialized countries since the mid-twentieth century. To such a system is the high level of the social and economic wellbeing of the citizens, as well as the existence of a perfect system of socio-economic institutions that direct the functioning of all elements of the system in order to achieve the goals of social justice, protection, a high standard and quality of life. For example, Western European countries, promoting the idea of social statehood, implement socio-economic policies not only at national but also supranational levels within the framework of a single European Union (EU) concept.

At the same time, according to the method of realization of the concept of socially oriented market economy and achieved effects, there is a certain difference between individual modifications of existing similar economic systems, which can significantly complicate understanding of the concept of the actual social economy.

An economy with a high standard of living and significant social expenditures (for example, the USA, Canada) is an example of a liberal society that has achieved a high level of material well-being that would allow significant allocations to the poor, financing the health care system, education, and other social sectors. However, there is a lack of a mechanism of reconciliation of interests between individual disparate social groups existing within the given economic system.

Instead, other economic systems (such as Switzerland, Austria, Belgium) are focusing their socioeconomic and legal mechanisms on concerted action to achieve social coherence and a high standard of living for most of the population, although they are in the lead in absolute terms of income and quality of life.

Accordingly, the status of a purely "social economy" can be assigned to the third group of countries, which successfully combine their own socially oriented market system to support the social sphere, to achieve a general level of well-being and high absolute indicators of sustainable development.

The social economy cannot be exceptionally free, liberal. In essence, the market, business is bypassing the implementation of social projects. In this case, it is extremely important for the functioning of the social market system to play the role of the state, which can either assume the maintenance of the functioning of the social sphere or create the conditions under which business will be forced or interested to participate in it. An ideal situation may be to create a high-income country, which, with the perfect income and expenditure 
component of the tax system, will allow the government to channel significant funds for social development while encouraging private business initiatives to engage in such programs and projects.

The expansion of the functions of the state in modern society while preserving market freedoms, institutions and mechanisms is conditioned by the further complication of the socio-economic process. Such fundamental problems of modern society as strengthening the social sphere cannot be solved solely through market mechanisms. The social sphere itself is one of the most important drivers of economic growth. Yes, the level of education, qualifications of the workforce, and the state of research directly affect the pace and quantitative indicators of economic growth. A significant impact on the quality of the workforce, on economic development as a whole, is exerted by the health care system, social security, and the environment. Alone, the market is not capable of creating a strong social sphere, although some market mechanisms, including competition, have a significant social orientation (Poirier, 2016).

The economic theory considers the possibility of manifestation of social effects in conditions of perfect competition. The social effect is «the totality of social results obtained from realization of investments in the real sector of the economy, which are projected on quality of the social environment»; "consequences of certain socio-cultural changes, mass events» (Schumpeter, 1984); a tool for creating "favorable conditions for the comprehensive development of the individual, the use by citizens of their creative forces and abilities, which find expression in the reduction of hard physical labor, an increase of free time, increase of material and cultural standard of living of the people, in health care, etc."; competitive product or service; the result that "society receives in the process of producing a product or service, performing a certain type of work, and in the process of consuming relevant social, material and spiritual values" (Stjernø, 2005). Important in this concept is the condition that the social effect must be stable, progressive, contain both the result of activity and the source, a means for further development, to act as a permanent and lasting element in the chain of continuous reproduction of social life.

The key indicators of social effect are: increasing the employment rate of the population; raising the level of housing supply; improving the environment; increasing accessibility and quality of services to the population in the fields of transport, health care, education, physical culture, and sports, culture, housing and communal services (SPI, 2018). Thus, activities aimed at achieving social impact can at the same time contribute to solving several important social problems.

However, the results from the social effect can be both positive and negative. On the one hand, the activity of market actors leads to job creation, improvement of living standards of the population, maintenance of ecological balance due to modernization of production and carrying out of environmental measures, an increase of educational and cultural level, reduction of social tension, etc. However, at the same time, we can 
observe job cuts (due to the same modernization of production), rising unemployment, lowing living standards, worsening environmental situation, the emergence of social tensions and social conflicts (for example, due to increased density of buildings, increased migration flows, etc.).

To overcome such negative features of the social orientation of the free functioning of the market, it is very important to clearly define the role, functional responsibilities, sphere of responsibility of the state, and mechanisms of its social control.

A special factor in the objective increase of the role of the state is the characteristic of modern society "institutional rigidity" - the presence of social and economic mechanisms that allow correlation of fundamental market variables in one direction and prevent changes in the opposite direction. For example, the absolute level of prices and wages usually increases, and when business conditions decline - lowering prices and wages, it is difficult to dismiss some employees due to regulatory factors. Although this indicates a partial loss of flexibility in the modern economy, it is only under such conditions that social standards can be respected and the general well-being of the population can be increased. This aspect is one of the important directions of the regulative state policy in the conditions of existence of the social market economy (Ehrenfreund, 2015). It should be borne in mind that economic efficiency is ensured solely by the market, though, in certain circumstances, with the participation and assistance of a state-controlled society.

This principle is universal in the current market conditions. There are, however, certain national peculiarities in which the functions of the market and the state in the existing separate national socio-economic system are differently distributed. It is in the model of social market economy that the optimal combination of the state and the market has been found in the form of active state intervention in the economy, especially in the social one, with absolute respect for the fundamental principles of a market economy.

Maintaining a competitive environment, protecting competition through the creation by the state of a perfect system of legislative acts, and mechanisms for monitoring their implementation are fundamental principles in the concept of a social market economy. Alone, a market system can easily lose its competitive character if it is not supported by exogenous non-market power.

In this case, the fundamental link is between competition and social well-being. Competition ensures the most efficient functioning of the market mechanism and thereby maximizes social wealth. Competition establishes a correlation between the income and expenditure of factors of production, between wages and labor costs, thus supporting social justice. Competition limits price increases and ensures that goods and services are accessible to most of the population. 


\section{CONCLUSIONS}

A socially-oriented market economy is a highly efficient economy with advanced entrepreneurship and market infrastructure, effective state regulation of income sharing that could interest businesses to expand and improve production, and workers to high levels of productivity. A socially oriented economy guarantees a high level of well-being for working members of a conscious society; adequate level of social security for poorly protected sections of the population - pensioners, unemployed, disabled, families with young children; effective protection of the life, health, rights, and freedoms of the general population.

The fundamentally social-oriented economy is based on the principles of constitutional guarantees of personal rights and freedoms of citizens, freedom, and responsibility of entrepreneurship, free choice of profession and place of work, equality of all forms of ownership, guarantees of its integrity and use in the interests of the individual and society, ensuring the interconnection of well-being and the results of their activities, social protection of the disabled and other socially disadvantaged sections of the population, social partnership based on three-parties system (government, employers, workers). In addition, any effective social economy considers and is characterized by national specific features that reflect the history of the country, the traditions of the people, the national mentality, the system of education and attitude to solidarity, collectivism/individualism, national peculiarities of business culture, etc. The highest value and purpose of development of society and the state is the person, his rights, freedoms, and guarantees of their realization (Miller, 2010). To ensure them, the state creates conditions for a sustainable and dynamic development of production, raising the standard and quality of life of the population based on the development of new systems of economy and technological way of production, formation of society considering cross-cultural characteristics.

In addition to creating economic and technical and technological conditions, the active participation of the state is the key to the effective functioning and sustainable development of the social economy. The role of the state must balance at the point of the plateau between the overarching dominant role of the state and its complete elimination from the process of economic progress. At the same time, social well-being cannot be achieved solely by employing market-based mechanisms, passive to efficient resource allocation, social and environmental problems, development security, etc. Seeking and achieving synergies, as well as the active participation of all participants in the socio-economic system, is a prerequisite for the effective socialization of economic processes.

In the conditions of exhaustion of certain resources, weakening due to the crisis phenomena of material positions and mechanisms of influence of the state regulatory system, ensuring a stable pace of development of both economic processes and their socialization is possible only in case of comprehensive involvement of all 
possible participants of this process. In this regard, the model of solidarity social economy as a kind of mixed market economic system is the first and actual in the modern world.

The social component of this model is realized through the focus on human resources. The presence of a market mechanism allows the participants of this system to receive income both from their direct operating activities and as a result both of projects implemented and of socialization aimed at quality reproduction of labor resources, growth of their quantity (due to the inclusivity of the labor market) and quality (due to urgent needs to ensure needs economics to education, medicine, etc.). The solidarity of the market economic system allows maximizing the above-described effects of the social economy through the interaction of all participants in the process, the synergy of social and market. In this model, the person acts not only as a resource and object of public policy but also as an active participant in economic development. A self-sufficient skilled highly competitive workforce does not need social protection but is itself able to become a driver of sustainable development.

An interdisciplinary approach to the study and formation of the economic system is an urgent requirement today. At present, the success of implementing a state economic policy operating under the conditions of a particular economic model depends on the diversity of aspects considered, one of the most important among which is social. The social aspect of the economic system and politics is oriented first and foremost to human resources. Its effective use is provided under the combination of economic, social, psychological, and cultural aspects of government. Thus, an interdisciplinary approach is key in exploring socioeconomic state systems and building, on their basis, a perfect model of state management.

FUNDING: The author did not receive any external funding.

CONFLICT OF INTEREST: The author declares no conflict of interest.

\section{REFERENCE}

1. Ehrenfreund, M. (2015). How income affects life expectancy. World economic forum. Available at: https://www.weforum.org/agenda/2015/09/how-income-affects-life-expectancy/

2. Esping-Andersen, G. (1990). The three worlds of welfare capitalism. Cambridge. Available at: https://www.researchgate.net/profile/Gosta-Esping- 
Andersen/publication/243774920_The_Three_Worlds_Of_Welfare_Capitalism/links/54116b240cf2b4da 1 bec4309/The-Three-Worlds-Of-Welfare-Capitalism.pdf

3. Janiszewska, D. (2015). The social market economy concept according to Alfred Muller-Armack. NARODOWA. The Polish Journal of Economics. DOI: https://doi.org/10.33119/GN/100835

4. HMR\&C - HM Revenue \& Customs. (2019). Guidance: Income Tax rates and allowances for current and past years. Available at: https://www.gov.uk/government/publications/rates-and-allowances-incometax/income-tax-rates-and-allowances-current-and-past

5. Kolev, Stefan; Goldschmidt, Nils; Hesse, Jan-Otmar (2014). Walter Eucken's Role in the Early History of the Mont Pèlerin Society. SSRN Electronic Journal. Institut für Allgemeine Wirtschaftsforschung. Available at: https://www.econstor.eu/bitstream/10419/90809/1/77707169X.pdf

6. Kuznetsova, E. (2015). Socialization as function of public administration. Omsk state technical university (64/66). MPRA. Available at: https://mpra.ub.uni-muenchen.de/66864/1/MPRA paper 66864.pdf

7. Laville, J-L. (2010). The Solidarity Economy: An International Movement. - Portuguese journal Revista Critica de Ciencias Sociais (2). DOI: https://doi.org/10.4000/rccsar.202

8. Merkel, A. (2019). Speech by Federal Chancellor Angela Merkel at the 49th World Economic Forum Annual Meeting in Davos on 23 January 2019. Available at: https://www.bundeskanzlerin.de/bkinen/news/speech-by-federal-chancellor-angela-merkel-at-the-49th-world-economic-forum-annualmeeting-in-davos-on-23-january-2019-1574188

9. Miller, E. (2010.) Solidarity Economy: key concepts and issues. Amherst, MA: Center for Popular Economics. Available at: https://www.socioeco.org/bdf fiche-document-429 en.html

10. NCGM - Nordic Cooperation: government and ministries (2019). An Open and Innovative Nordic Region with Healthy People 2020: Equal Opportunities for Welfare, Culture, Education, and Work. Available at: https://stm.fi/en/nordic-cooperation/an-open-and-innovative-nordic-region-with-healthypeople-2020

11. Pelkmans, J. (2012). The Economics of Single Market Regulation. Department of European economic studies: Bruger European Economic Policy Briefings (25). Available at: https://core.ac.uk/download/pdf/132578413.pdf

12. Poirier, Y. (2016). Legal and political recognition of social solidarity economy (SEE): An overview on SSE public policies and guidelines. International network for the promotion of social solidarity economy (RIPESS). Available at: http://www.ripess.org/legal-and-political-recognition-of-social-solidarityeconomy-sse-an-overview-on-sse-public-policies-and-guidelines/?lang=en

13. Pryyatelchuk, O. (2018). State social-economic policy in the frame of European model of social economy. Imperatives of development of civil society in promoting national competitiveness. 
14. Pryiatelchuk, O.A. (2019). Formuvannia sotsialno-oriientovanoi ekonomichnoi systemy derzhavy yak instytutsiina osnova sotsializatsii biznesu. Novitni formy mizhnarodnoho biznesu v umovakh hlobalnykh instytutsiinykh ta tekhnolohichnykh zmin: kolektyvna monohrafiia. - Kyiv: VADEKS: 238-249.

15. REO - Regional Economic Outlook (2019). Europe: Facing Spillovers from Trade and Manufacturing. International Monetary Fund. Available at: https://www.imf.org/en/Publications/REO/EU/Issues/2019/10/24/REO-EUR-1119

16. Reinert, E. 1999. The Role of the State in Economic Growth. Journal of Economic Studies (26): 268-326. MCB University Press. DOI: https://doi.org/10.1108/01443589910284903

17. Schumpeter, J. 1984. The meaning of rationality in the social sciences. Mohr Siebeck. 140 (4): 577-93. Available at: https://www.jstor.org/stable/40750743

18. SPI (2018). Social Progress Imperative: Social Progress Index. Available at: https://apo.org.au/sites/default/files/resource-files/2020-09/apo-nid308352.pdf

19. Strategy (2020). Europe 2020: A European Strategy for smart, sustainable and inclusive growth. Available at: https://ec.europa.eu/eu2020/pdf/COMPLET\%20EN\%20BARROSO\%20\%20\%20007\%20\%20Europe\%202020\%20-\%20EN\%20version.pdf

20. Stjernø, S. (2005). Solidarity in Europe: The History of an Idea. Cambridge: Cambridge University Press. Available at: https://voidnetwork.gr/wp-content/uploads/2016/09/Solidarity-in-Europe.The-History-ofan-idea-by-Steinar-Stjerno.pdf 